\title{
FloTrac System
}

National Cancer Institute

\section{Source}

National Cancer Institute. FloTrac System. NCI Thesaurus. Code C129634.

A proprietary device system comprising a sensor and a monitor for continuous

determination of a patient's fluid status and cardiac output directly from the arterial line. 